\title{
炎症性腸疾患治療における生物製剤の現状
}

久松理一, 日比紀文

\section{Biologics in Current Therapy for Inflammatory Bowel Disease}

Tadakazu Hisamatsu, M.D., Ph.D. and Toshifumi HiBI, M.D., Ph.D.

Division of Gastroenterology and Hepatology, Department of Internal Medicine, School of Medicine, Keio University

(Received April 6, 2009)

\section{summary}

Recent advance of molecular biology and immunology contributes to the development biologics such as anti-TNF $\alpha$ agent in the treatment for inflammatory bowel disease (IBD). Although therapeutic strategy of IBD has not been changed for a long time, success of Infliximab, first anti-TNF $\alpha$ agent, now changes therapeutic strategy of IBD dramatically. Top-down strategy has been considered to improve patients' natural history in the therapy for Crohn's disease as well as in rheumatoid arthritis. Infliximab also has been expected as a promising medicine for pediatric Crohn's disease. Furthermore, Infliximab has been approved for the therapy of ulcerative colitis. These tremendous successes of Infliximab have encouraged us to develop other anti-TNF agents and other biologics. In this review, we describe current topics of biologics in IBD treatment and discuss future direction.

Key words_ _ inflammatory bowel disease; biologics; TNF $\alpha$

抄 録

炎症性腸疾患の病態については遺伝分子生物学・免疫学の進歩による解明が進み, 機能分子の同定とそれを標的 とする治療法の開発が進んでいる，その最たる成功例がヒトマウスキメラ型抗 TNF $\alpha$ 抗体である Infliximabである. Infliximabの登場はクローン病治療体系に革命をもたらし，Top-down therapy としての早期からの使用や潰瘍性大 腸炎への適応の検討も始まっている．また，Infliximab に追随するようにさまざまな TNF 阻害剤や新たな分子を 標的とした生物製剤が開発され臨床応用されつつある.

\section{I. はじめに}

炎症性腸疾患は原因不明の非特異的慢性炎症を消 化管に生じる病気で狭義にはクローン病と潰瘍性大 腸炎に区別される. 両疾患之も厚生労働省難病特定 疾患に指定されている. 欧米での有病率が極めて高 く，一昔前では日本では稀な疾患であると考えられ てきたが，しかしながら，本邦での患者数も年々増 加傾向にあり, クローン病で現在約 25000 人，潰瘍 性大腸炎で 90000 人をこえ，炎症性腸疾患 10 万人 時代を迎えつつある（図 1）。 また難治例の増加， 20 代を中心とした若年での発症が多いことより， 就学や就労への障害あるいは経済的負担など多くの 社会問題を生み出している.

炎症性腸疾患は疾患関連遺伝子に代表される遺伝

慶應義塾大学医学部消化器内科
的因子, 食事などの環境因子, 免疫学的異常が複雑 に絡み合った多因子疾患と考えられている．特に腸 内細菌との免疫学的調和の破綻が病因として注目さ れてきている（図2）. 疫学的には我が国の炎症性 腸疾患の増加は食事の欧米化, とくに肉類の摂取量 や脂肪の摂取量の増加と相関しているとされる.

クローン病は，口から肚門までの全消化管を侵し 発熱・腹痛・下痢・肛門病変などを主訴とし, 再燃 と緩解を繰り返す原因不明の炎症性腸疾患である. 標的蔵器としては小腸, 大腸が好発部位であり, 病 変が不連続に多発し (skip lesion), 縦走潰瘍や敷 石状配列といった特徵的な内視鏡像やX 線像を呈 する潰瘍病変や瘻孔の形成が特徵的である. 潰瘍性 大腸炎は主に大腸が侵される疾患で直腸からの連続 性, びまん性の病変分布が典型的である. 両疾患と もに腸管外合併症として虹彩炎, 関節症状, 結節性 紅斑や壊疽性膿皮症などの皮膚病変を合併すること 
潰瘍性大腸炎

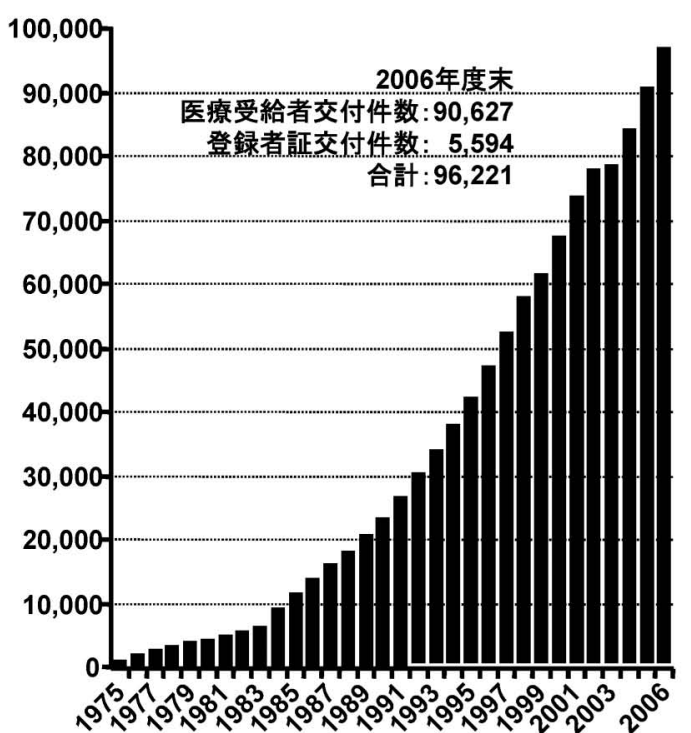

年度
クローン病

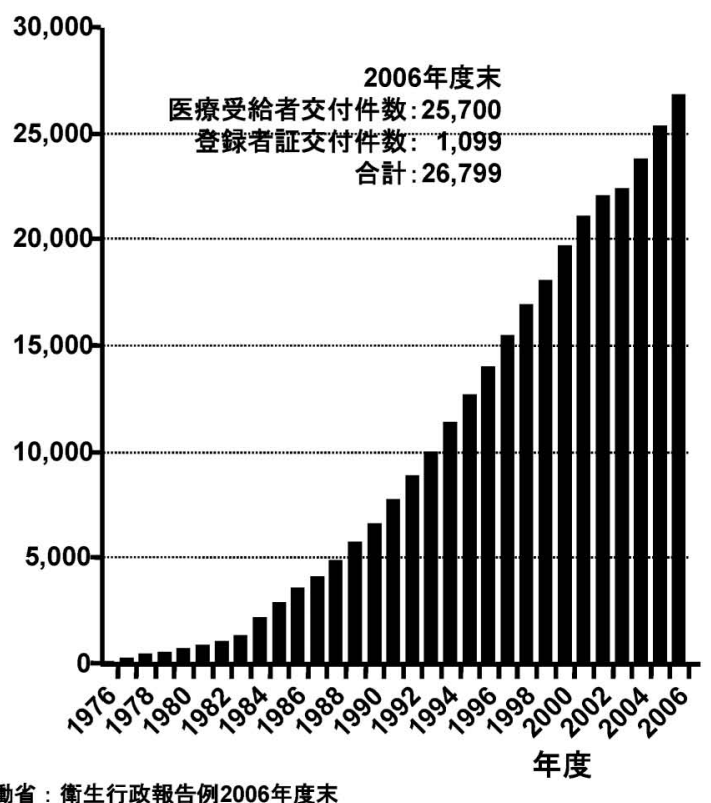

図 1 炎症性腸疾患の患者数推移

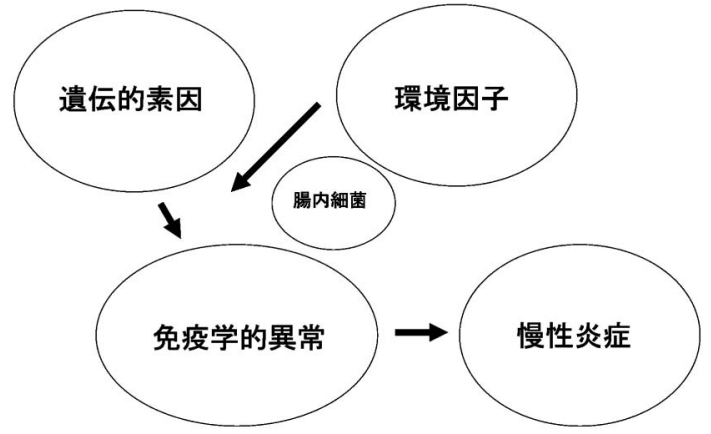

図 2 炎症性腸疾患の病因

\section{がある（表 1）（図 3A，B）。}

\section{II. 我が国の炎症性腸疾患治療の変遷}

図 4 に示すように我が国の炎症性腸疾患の治療の スタートは 1970 年代に始まった。はじめは薬物療 法としてはスルファサラゾピリジン，副腎皮質ステ ロイド剤が中心で，加えてクローン病では成分栄養 剂を用いた経腸栄養療法が用いられた。 AZA や 6MP といった免疫調節剤は慶應義塾大学をはじめと する一部施設ではすでに 1970 年代から用いられて きたが普及したのは 1990 年代後半になってからで ある。これには後述するように infliximab（商品 名：Remicade）の承認にともない免疫調節剤の併 用を行なう症例が増えたことも関係していると思わ れる，欧米ではすでに複数の TNF 阻害剤がクロー
ン病のみならず潰瘍性大腸炎でも承認されている. さらに $\alpha 4$ インテグリン抗体である Natalizumab （商品名：TYSABRI）もクローン病に対して条件 付ながら承認された. 日本ではクローン病に対して 2002 年に Infliximab の緩解導入療法, 2007 年に緩 解維持療法が承認されている. その後 Adalimumab (商品名: Humira), Certolizumab pegol（商品名： CIMZIA）の臨床治験が行なわれ，また現在 $\alpha 4$ イ ンテグリン阻害剤の AJM300 の臨床試験がスター トしている，潰瘍性大腸炎に対してはinfliximabの 臨床試験が終了し承認が期待されている.さらに Adalimumab や Golimumab といった改良型の TNF 阻害剤の臨床試験もスタートした。

炎症性腸疾患の治療では長い間完治に向けた治療 法あるいは QOL を改善する治療法の開発が切望さ れてきた。この膠着状態を大きく打破したのが炎症 性サイトカインを標的とした分子標的薬, 抗 TNF $\alpha$ 抗体製剂の出現である. Infliximab の出現は炎症性 腸疾患治療戦略を根本から大きく変えつつある.

III. クローン病治療における Infliximab（商品名： Remicade）の導入の経緯

クローン病の原因に関してはいまだ不明である が，遺伝的素因などを背景として食飭抗原や腸内細 菌などの腸管腔内の抗原に対する免疫異常が生じた 多因子疾患であるという考えが現在の主流である。 
表 1 クローン病と潰瘍性大腸炎の鑑別

\begin{tabular}{|c|c|c|}
\hline & クローン病 & 潰瘍性大腸炎 \\
\hline 発症年齢分布のピーク & 男子 $20 \sim 24$ 歳, 女子 15〜19 歳 & $20 \sim 24$ 歳 \\
\hline 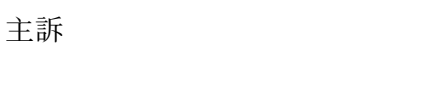 & $\begin{array}{l}\text { 下痢, 腹痛, 体重減少, 成長障害 } \\
\text { 発熱, 難治性痔瘻など }\end{array}$ & 持続する下痢, 粘血便, 腹痛 \\
\hline 罹患臓器 & ロから肛門まで全消化管 & 大腸 \\
\hline \multirow[t]{6}{*}{$\mathrm{X}$ 線検査抢よび内視鏡像の特徵 } & skip lesion & びまん性病変 \\
\hline & 敷石状配列（cobblestone appearance） & 直腸からの連続性病変 \\
\hline & 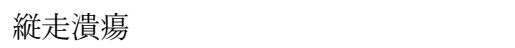 & 鉛管現象（lead pipe phenomenon） \\
\hline & 瘻孔 & \\
\hline & 狭窄 & \\
\hline & 上部消化管病変 & \\
\hline \multirow[t]{2}{*}{ 肛門病変 } & 肛門周囲膿瘍 & 肛門周囲膿瘍 \\
\hline & 難治性痔瘻 & \\
\hline \multirow[t]{3}{*}{ 病理学的所見 } & 全層性炎症 & 粘膜主体の炎症 \\
\hline & 非乾酪性肉芽腫 & 杯細胞の減少 ～～～～～～～～ \\
\hline & & crypt abscess（ただし特異的ではない） \\
\hline
\end{tabular}

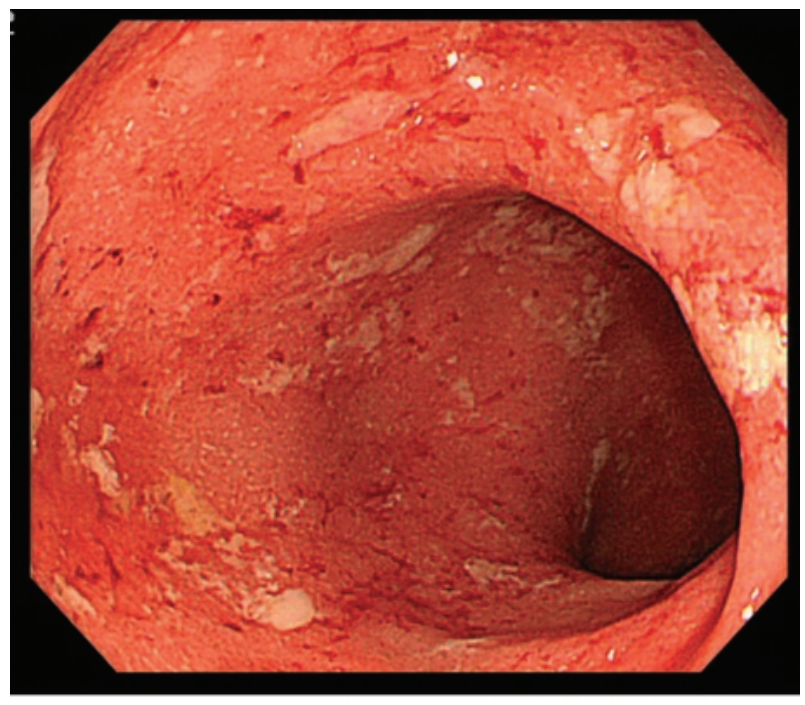

A. 潰瘍性大腸炎

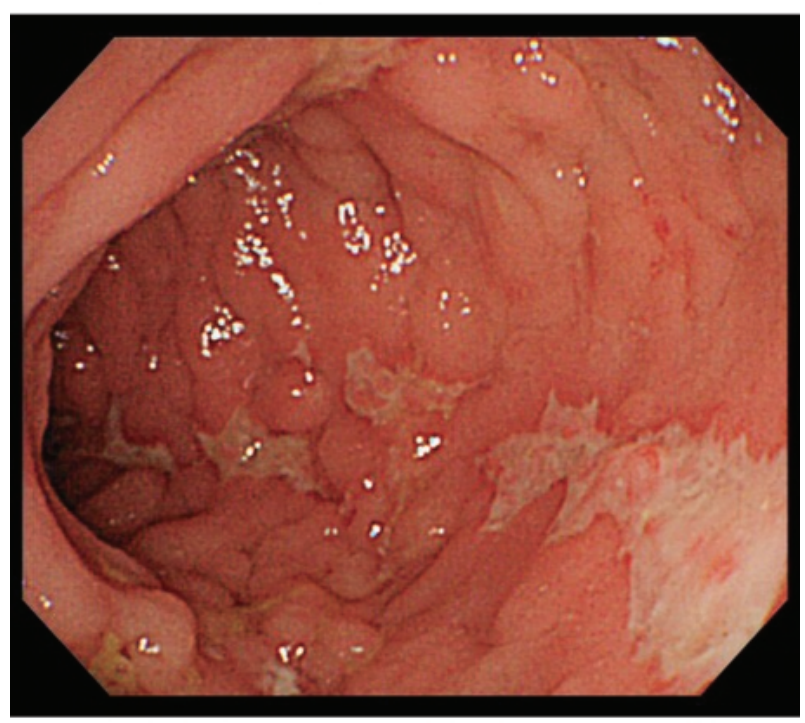

B. クローン病

図 3 炎症性腸疾患の内視鏡像
クローン病では種々のサイトカインの産生異常が認 められ, その結果, 病変局所では複雑なサイトカイ ンネットワークを形成している。これらのサイトカ インを標的とした各種のモノクローナル抗体や阻害 剤の開発が行われているが，中でも既に実用化され 劇的な有効性で注目を集めているのが抗 $\mathrm{TNF} \alpha$ 抗 体, Infliximab（商品名：Remicade）である. Infliximab は $75 \%$ がヒト， $25 \%$ がマウス由来のキメ ラ型抗 $\mathrm{TNF} \alpha$ モノクローナル抗体である.

$\mathrm{TNF} \alpha$ はさまざまな炎症性サイトカインやケモカ イン，接着因子などの発現を誘導する。これらの因 子は炎症部位への白血球の遊走, 白血球の活性化, および急性期蛋白の産生に関与している．以前より クローン病患者では血清中 · 糞便中 · 病変部粘膜中 での $\mathrm{TNF} \alpha$ の産生六進が報告されていた. 1993 年 に病態に打ける免疫異常にクローン病との共通点を 有する関節リウマチに対する抗 $\mathrm{TNF} \alpha$ 抗体の有用 性が報告された1). クローン病では，1995 年に初の 臨床治験の結果がオランダより報告され, 単回投与 を受けた 10 例の活動期クローン病患者中 8 例で 4 週後に緩解導入に成功したことが報告された ${ }^{2)}$. 1997 年には Targan らが活動期クローン病患者 108 例を対象とした多施設二重盲検比較試験を行ない, Infliximab $5 \mathrm{mg} / \mathrm{kg}$ 投与群では投与 4 週間後に $81 \%$ の有効率が得られ注目された ${ }^{3)}$. Infliximabの高い 治療効果は内視鏡所見拈よび組織学的所見によって も裏付けられ4), Infliximab は治療抵抗性のクロー ン病に対する緩解導入のための特効薬として位置づ けられるようになった。 また Present らによって行 


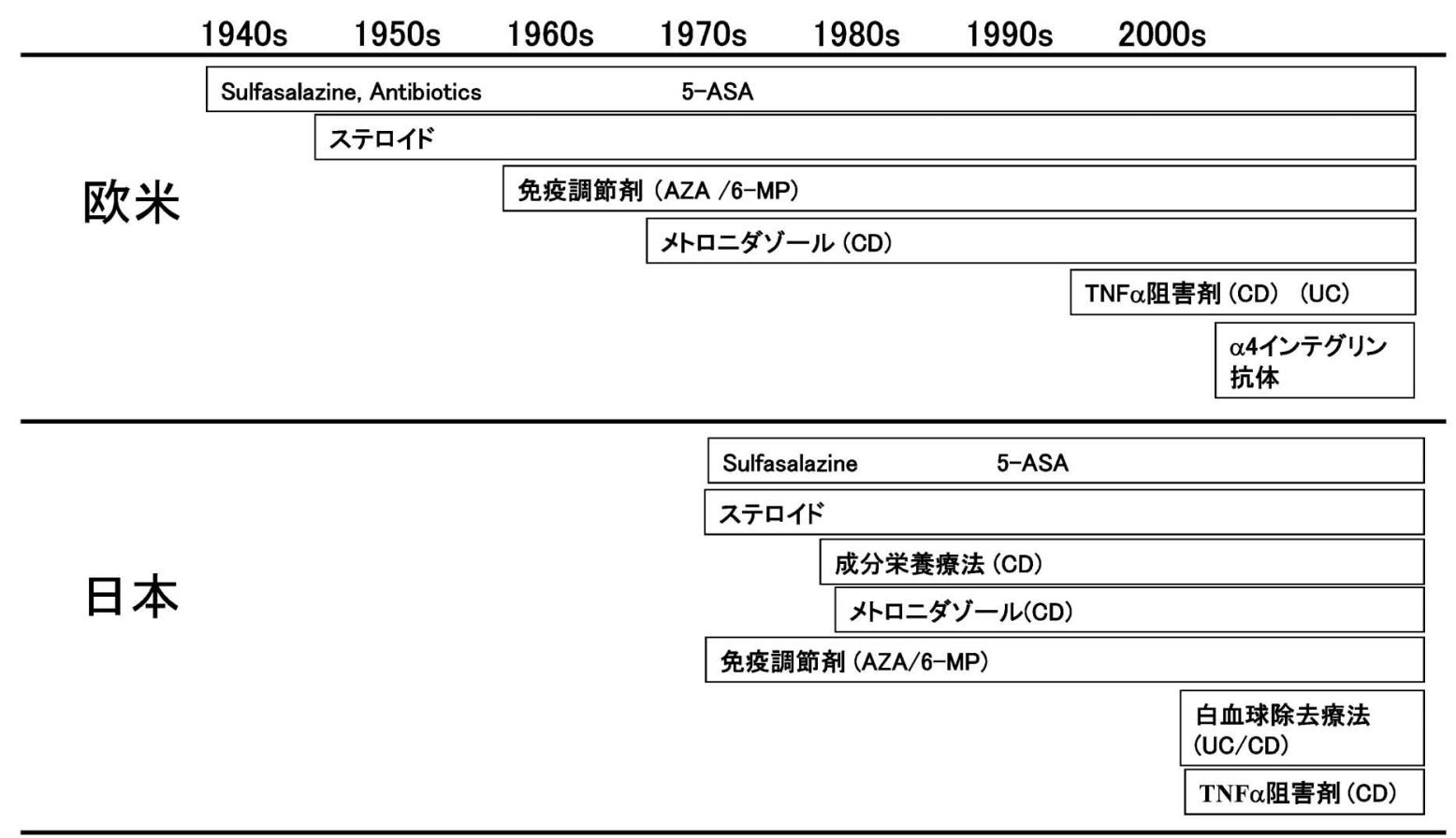

図 4 炎症性腸疾患治療の推移

われた瘻孔治療効果に対する無作為二重盲検比較試 験では, Infliximab $5 \mathrm{mg} / \mathrm{kg}$ または $10 \mathrm{mg} / \mathrm{kg}$ を0, 2, 6 週に投与したところプラセボ投与例に比し有効 率が有意に高い（68\%抢よび 56\% vs 26\%）ことが 示された ${ }^{5)}$. 本邦でもようやく 2002 年 5 月に緩解 導入療法としての使用に保険適応が認められ，中等 度〜重度の活動性クローン病を有し，従来の治療法 が無効であった患者, ならびに瘦孔性の疾患を有す る患者に対して Infliximab の使用が合計 3 回（0，2， 6 週）に限り可能となった.

このように単回投与における緩解導入を含めた劇 的な効果が多数報告されてきた一方，長期的な経過 では再燃が避けられないことがわかってきた。Infliximab の一回投与により得られる血中濃度を測定 すると，検出可能なのは約 8 週までである. そこで Rutgeerts らはInfliximab を 8 週ごとに 4 回反復投 与したところ, 緩解維持率は Infliximab 群で有意に 優れていたことを報告した6)。これをもとに 2001 年に大規模臨床試験 (A Crohn's Disease Clinical Trial Evaluating Infliximub in a New Long-Term Treatment Regiment I : ACCENT I) が行われ, 中 等度〜重度のクローン病患者に対し維持療法として Infliximab を反復投与すると, 有効期間および緩解 期間が延長することが示された7).

瘻孔治療効果においても長期連続投与の有用性が 報告されている. 大規模臨床試験 ACCENT II に抢
いて Sands らは外瘻を有するクローン病患者 306 人に対し， 8 週に 1 回の連続投与群と初回 3 回+プ ラセボ投与群に分け，瘻孔閉鎖率を比較した。その 結果, 54 週後の外瘦完全閉鎖率は Infliximab 長期 連続投与群で有意に高値 (36\% vs 19\%) を示した ${ }^{8)}$.

さらに維持療法の有効性を示した試験である ACCENT I の患者を対象にした追加報告では再燃 時の episodic 投与よりも定期的に投与を決めてお く scheduled 投与の成績が上回ったことから欧米で は初回投与が有効であった症例にはその後 8 週ごと の維持投与が推奨されるようになった ${ }^{9)}$. 我が国で も 2007 年 11 月に維持療法の効能追加が認められた.

Infliximab の作用機序に関しては, 当初, 速やか に可溶型 TNF $\alpha$ に対する中和する作用，ならびに 受容体に結合した TNF $\alpha$ を解離させる作用によ り, クローン病患者の腸管粘膜に打ける $\mathrm{TNF} \alpha$ 活 性を抑制し，抗炎症効果を発揮しているものと考え られていた。現在では Infliximab は膜結合型 TNF $\alpha$ にも結合し，CDC ( complement-dependent cytotoxicity) 活性および ADCC (antibody-dependent cellular cytotoxicity）活性を介して膜型 TNF $\alpha$ 陽性 細胞のアポトーシスを誘導することも知られてお り10,11), 他の TNF $\alpha$ 阻害剤と比較しユニークな点で ある.さらにマウスモデルの検討で腸管上皮細胞に 発現した TNFR-1 を介した腸管上皮細胞のアポ トーシスが腸炎発症に関わっている可能性が示唆さ 
れている ${ }^{12-14)}$. Infliximab がその中和作用で上皮細 胞障害を防いでいるという仮説は Infliximab で認め られる速やかな腸管粘膜修復作用 (mucosal healing）にも合致しており興味深い。実際, Zeissig ら は Infliximab 使用後で腸管上皮細胞のアポトーシス が減少していることを報告している15)。

\section{IV. 次々に開発導入される TNF $\alpha$ 阻害剂}

Infliximabの劇的な有效性が明らかとなって以 来，さまざまな $\mathrm{TNF} \alpha$ 阻害剤が開発されつつあ り，慢性炎症疾患（関節リウマチや炎症性腸疾患） 治療薬において最も注目されている領域となってい る.

\section{Adalimumab（商品名：Humira）}

Infliximab はマウスとのキメラ抗体であるため Infliximab 自体に対する抗体産生が起こることがあ る.これに対し完全ヒト型の TNF $\alpha$ 抗体として開 発されたのが Adalimumab である. Infliximab に副 作用を認めた 7 例の Crohn 病に対する adalimumab の pilot study の結果が報告され16)，その後 3 つの 大規模臨床試験, CLASSIC I, Clinical assessment of Adalimumab Safety and efficacy Studied as Induction therapy in Crohn's disease ${ }^{17)}$; CHARM, Crohn's Trial of the fully Human Antibody Adalimumab for Remission Maintenance ${ }^{18)}$; GAIN, Gauging Adalimumab Efficacy in Infliximab Nonresponders ${ }^{19)}$ が行われた。CLASSIC I 臨床試 験では TNF 阻害剤の使用経験のない中等症から重 症のクローン病患者 299 例を対象に第 0 週， 2 週の 投与による緩解導入効果が検討された。 低用量 $(40$ $\mathrm{mg} / 20 \mathrm{mg})$, 中等量 $(80 \mathrm{mg} / 40 \mathrm{mg})$, 高用量 (160 $\mathrm{mg} / 80 \mathrm{mg})$, プラセボからなる 4 群の比較において 第 4 週の緩解導入率はプラセボ群の $12 \%$ に対しそ れぞれ 18\%（p=0.36）, 24\%（p=0.06）, 36\%（p= 0.001) であった。CHARM 試験では 56 週間の緩 解維持効果に関する検討が行われ，第 0 週に 80 $\mathrm{mg}$, 第 2 週に $40 \mathrm{mg}$ が投与され第 4 週時点で有効 であった 499 例を対象に $40 \mathrm{mg}$ 隔週投与群, $40 \mathrm{mg}$ 毎週投与群, プラセボ投与群で比較された。第 26 週の時点での緩解率はそれぞれ $40 \%, 47 \%, 17 \%$ で 第 56 週においては $36 \%, 41 \%, 12 \%$ であり実薬群 での緩解維持効果が明らかとなった。 GAIN 試験で は Infliximab 無効例あるいは副作用により Infliximab が投与できない症例に対する緩解導入効果に
関する検討がなされ，Adalimumab は Infliximab 無 効例や副作用で使用できない症例にも有効であるこ とが示された. 現在わが国でも緩解導入効果と維持 効果に関する臨床試験が進行中である.

\section{Certolizumab pegol（商品名：CIMZIA）}

Schreiber らは certolizumab pegol のクローン病 に対するランダム化プラセボ比較試験の結果を報告 している20) . certolizumab pegol は PEG 化された 抗 $\mathrm{TNF} \alpha$ 抗体の Fab fragment である. 本臨床試験 は 292 名の中等度から重症のクローン病患者を対象 に行なわれ，12 週の時点で容量依存性に有効性が 確認された。しかしながら本臨床試験では primary end point を有効率に設定しており緩解率としてい ないことや，CRP 高值例に限った場合でのみ有効 性に差が認められたなどの課題が残された。このた め引き続いて二つの大規模臨床試験 PRECISE 1; Pegylated Antibody Fragment Evaluation in Crohn's Disease: Safety and Efficacy $1^{21)}$, PRECISE 2; Pegylated Antibody Fragment Evaluation in Crohn's Disease : Safety and Efficacy 222) が行われた. PRECISE 1 試験に掞いて Certolizumab pegol は 662 例 の中等症から重症のクローン病患者を対象にプラセ ボ群との二重盲検比較が行われた。実薬投与群 (Certolizumab pegol $400 \mathrm{mg}$ を第 0, 2, 4, 週に皮下 注し以後 4 週毎に維持投与） で第 6 週, 第 26 週の 時点でプラセボ群に比較して有効率で有意差を認め たが，それぞれの時点での緩解率には有意差は認め られなかった. PRECISE 2 試験は緩解導入療法が 有効であった症例に対して実薬群とプラセボ群の維 持投与効果を比較したもので，その結果，緩解導入 療法が有効であった患者においては第 26 週時点で の緩解率は実薬投与群が上回っていた.

これらの報告を見る限りCertolizumab pegol の 緩解導入効果は決して十分なものとは言えないが他 の抗 TNF 阻害剂が使用できない症例に試みる価值 はあろう。わが国でも現在臨床試験が進んでいる. 現在使用されている Infliximab の作用機序の一つと して先に述べたように膜型 $\mathrm{TNF} \alpha$ 発現細胞に対す るアポトーシス誘導効果が考えられているが，Fab fragment である Certolizumab pegol ではこの機序 が働かないことが上記のような臨床試験の結果を反 映しているのかもしれない。 


\section{Etanercept（商品名： Enbrel）}

可溶性 TNF $\alpha$ 受容体である Etanercept は関節リ ウマチでの有効性が示されていたのにもかかわらず クローン病に対する治療効果は Infliximab ほど期待 されたものではなかった23)。興味深いことに Etanercept はクローン病の腸管病変には明らかな有 効性が確認されなかったが関節症状には有効であっ たとする報告もある24)．この両薬剤の有効性の違い についての詳細はいまだ解明されていないが，先に 述べた粘膜固有層局所の免疫細胞に対するアポトー シス誘導作用の有無の違いが考えられる.クローン 病における Infliximab の作用機序は soluble TNF $\alpha$ の中和だけでなく $\mathrm{Fc}$ 部分を介した腸管局所に存在 する膜型 $\mathrm{TNF} \alpha$ 産生細胞に対する積極的なアポ トーシス誘導作用が関与しているものというもので ある10).

\section{Golimumab}

Centcore 社の開発した Golimumab は完全ヒト化 型抗 $\mathrm{TNF} \alpha$ 抗体で, Infliximab の 2-4 倍の可溶性 $\mathrm{TNF} \alpha$ に対する中和作用を有する．投与経路は皮下 注射で用いられる. 現在, 我が国を含めて潰瘍性大 腸炎に対する国際共同治験が行なわれている.

\section{TNF 阻害剤は免疫調節剤と併用すべきか ?}

TNF 阻害剂の出現以前では緩解維持療法として 有効であるというエビデンスが得られていたのは潰 瘍性大腸炎では 5-ASA 製剂と AZA や 6-MPなど の免疫調節剂, クローン病では免疫抑制剂と我が国 のデータが主体であるが成分栄養剤による在宅経腸 栄養療法であった．図４に示したように免疫調節剤 は我々をはじめとする一部の施設では 1970 年代か ら用いられてはいたが，標準治療として使用される ようになったのは最近のことである.我が国で免疫 調節剤が広く使用されようになった理由のひとつと して Infliximab の episodic な使用法が導入されたと き Infliximab に対する抗体出現を抑えるために免疫 調節剤の併用が推奖されたことも大きい25)。しか し，その後 Infliximab の scheduled maintenance 治 療が確立し, 同治療法では抗体出現率が低下するこ とが分かり，免疫調節剂の併用の必要性が議論にな っている. 2008 年 12 月にフロリダで行われた Crohn's \& Colitis Foundation of America (CCFA) のミーティングにおいても topics として扱われ た。 小児クローン病の分野では免疫調節剤は併用せ
ず Infliximab などの TNF 阻害剂の monotherapy を 行うという意見が多かったが，これは免疫調節剤併 用時の悪性リンパ腫, 特に hepato-splenic T cell lymphomaのリスクを考慮したものであると考えら れる. 一方, 現在進行中の SONIC 試験 (Study of Biologic and Immunomodulator Naive Patients in Crohn's Disease）の途中経過では Infliximab 単独投 与群と比較して Infliximab と azathiopurine 併用群 で緩解率が高いという結果が報告されている．この ため当初は併用療法で緩解導入し, その後 Infliximab 単独による維持療法に切り替えるという意見 もある.TNF 阻害剂と免疫調節剂との併用の是非 については SONIC 試験の最終結果含め今後の臨床 研究の結果が待たれるところである.

\section{TNF 阻害剤はクローン病の予後を変えうる か?}

臨床応用され始めた当時は, 生物製剂ということ もあり Inflximab は通常の治療に抵抗性の難治例に 対する最終兵器的印象を持たれていた. しかしその 有効性が明らかになるにつれてより早期から Infliximab 治療を導入すべきではないかという考え方が 出てくるのは必然である26).この Top-down therapy という治療戦略は関節リウマチで先行してい る. 関節リウマチに抢ける不可逆的な骨破壊や関節 変形を防ぐためより早期から強力な治療介入をすべ きであるというものである. 2005 年に早期関節リ ウマチに対するさまざまな治療介入による長期的な 骨破壞の予後の検討（the BeSt Study）の結果が報 告された。この検討で infliximab を早期から使用し た群で 1 年後の X 線による骨破壊像が有意に少な かった ${ }^{27)}$.このような結果を踏まえ, クローン病に おいても瘻孔などの治療に難渋する合併症を生じる 前に積極的に Infliximab で治療介入していくことで 患者の将来的な QOL が改善できるのではないかと いう考え方がなされるようになりつつある。 D'Haens らは最初から Infliximab とアザチオプリ ンを投与した Top-down グループでは従来型のス テロイド治療からはじまる Step-up 治療に比較して 治療成績が優れていたと報告している ${ }^{28)}$ 。この試験 は open ラベルであり, Infliximabの投与も計画的 維持投与がなされていないなど Top-down therapy と従来からの Step-up therapy を厳密に比較した臨 床試験としては不十分な点もあるが，いったん瘻孔 や狭窄を生じたクローン病は治療に難渋し患者の 
QOL は著しく低下することが多いことから早期か らの Infliximabによる治療介入はクローン病の治療 体系を考えていく上で極めて重要な課題であると思 われる. Top-down therapy に対する臨床医の懸念 の多くは開始時期と適応症例をどう決めるのか, 長 期継続使用に伴う副作用の問題, 医療コストなどに あると思われ，治療効果の久ならずこれらの点につ いても検討が必要である.

\section{VII．小児クローンに対する Infliximab 治療}

臨床試験の結果は小児クローン病に対する Inflix$i m a b$ 治療の高い有効性を報告している，中等症か ら重症の小児クローン病患者を対象に行われた REACH 試験において Infliximab $5 \mathrm{mg} / \mathrm{kg}$ の第 0 , 2,6 , 週投与による緩解導入療法に反応した症例に 対して 8 ないし 12 週ごとの維持投与が行われた. 第 10 週の時点で $88.4 \%$ の患者に有効性が認められ $58.9 \%$ の患者が緩解導入に至った。第 54 週の時点 では 8 週毎の維持投与群で有効率 $63.5 \%$, 緩解率 は $55.8 \%$ であった ${ }^{29)}$.この結果は成人に対する成 績と比較しても同等以上のものであり，小児クロー ンが Infliximab 治療のよい適応であることを示唆し ている，小児クローン，言い換えれば病歴が浅い時 期のほうが Infliximabの効果が大きいのではないか という考え方も成り立ち，先に述べたTop down therapy を支持する根拠にもなっている．小児ク ローンの場合ステロイド剤や栄養不良による成長障 害が問題になることが多く，この点からも Infliximab 治療は期待が大きい.

\section{VIII．潰瘍性大腸炎に対する TNF 阻害剂}

中等症から重症潰瘍性大腸炎に対する Infliximab 治療のランダム化プラセボ比較試験の結果も報告さ れ， 3 力月後の手術移行率を primary end point した場合, Infliximab 群では 24 例中 7 例, placebo 群では 21 例中 14 例と Infliximab 群で有意差をもっ て手術回避が可能であり, “rescue therapy”として の有効性が示された ${ }^{30)}$.

さらに Rutgeertsらにより活動性潰瘍性大腸炎に 対する Infliximab 治療のランダム化プラセボ比較二 重盲検試験 (the Active Ulcerative Colitis Trials 1 and 2: ACT1 and ACT2)の結果が報告された ${ }^{31)}$.

$\mathrm{ACT} 1$ 抢よび ACT2 両試験ともに中等度から重症 の活動性を有する潰瘍性大腸炎 364 名を対象に行な われた. Placebo と $5 \mathrm{mg} / \mathrm{kg}$ または $10 \mathrm{mg} / \mathrm{kg} の$
Infliximabを $0,2,6$ 週およびその後 8 週ごとの連 続投与を行い, ACT1 では 54 週, ACT2 では 30 週 の経過観察後に評価がなされた. ACT1 では 8 週後 の時点で $5 \mathrm{mg} / \mathrm{kg}$ の投与を受けた患者の $69 \%, 10$ $\mathrm{mg} / \mathrm{kg}$ 投与群では $61 \%$ に有効で (placebo 群 $37 \%$ ), 54 週の時点での緩解率は $5 \mathrm{mg} / \mathrm{kg}, 10 \mathrm{mg} / \mathrm{kg}$ 投与 群の両者で $42 \%$ （placebo 群 $20 \%$ ）であった。 ACT2 でも 8 週後の有効率は $5 \mathrm{mg} / \mathrm{kg}$ 投与群で 64 $\%, 10 \mathrm{mg} / \mathrm{kg}$ 投与群で $69 \%$ と placebo 群の $29 \%$ よ りも有意に高かった。 維持効果についても ACT1 において $5 \mathrm{mg} / \mathrm{kg}, 10 \mathrm{mg} / \mathrm{kg}$ の維持投与群では緩解 が維持できた症例はそれぞれ $19.8 \%, 20.5 \%$ と placebo 群の $6.6 \%$ よりも有意差をもって確認され た。

以上の結果より，急性期の緩解導入療法としては シクロスポリンの持続静注療法とほぼ同等程度の有 効性を持ち，汃維持効果を有するInfliximab の scheduled therapy は中等症から重症の潰瘍性大腸 炎治療の主役となる可能性を秘めている. 我が国で も Infliximab の臨床試験が終了ている.さらに Adalimumab の臨床試験や Infliximab よりも強力な $\mathrm{TNF} \alpha$ 中和能を有する Golimumab の臨床試験も開 始されている．特に AdalimumabとGolimumab の 両者は皮下注射で投与することができ外来通院治療 に大きなメリットがあると思われる，このように潰 瘍性大腸炎の治療体系が TNF 阻害剂の導入により 大きく変わらうとしている.

\section{IX. 他の分子標的薬}

\section{1. ヒト化抗 IL-6 受容体抗体（Tocilizumab 商 品名：ACTEMRA)}

ヒト化抗 IL-6 受容体抗体（Tocilizumab）はすで に国産初の抗体医薬品としてキャスルマン病に対す る治療薬として承認されている.さらに 2008 年 4 月, 既存治療に効果不十分な関節リウマチならびに 若年性特発性関節炎に対して適応追加がなされた。 クローン病に対しては国内でパイロット試験が行わ れその有効性が示されている32). 活動性クローン病 患者 36 例を実薬 $8 \mathrm{mg} / \mathrm{kg}$ を 2 週ごと, 4 週ごと点 滴投与する群とプラセボ群の 3 群比較において 12 週目の有効率が実薬群で有意差をもって高かった。 また，抗核抗体や抗 DNA 抗体の出現は認めず安全 性も高いと考えられた. クローン病に対する大規模 臨床試験はまだ始まっていないが適応拡大が期待さ れている製剤のひとつである. 


\section{2. 抗 IL-12p40 抗体（ABT-874/J695）}

クローン病の病態には局所の IFN- $\gamma$ 産生え進に 代表される Th-1 免疫応答へのシフトが中心的な役 割を果たしていると考えられるが，その Th-1 免疫 応答を誘導するサイトカインである IL-12 に対す るヒト化モノクローナル抗体 ABT-874/J695 の有 効性が報告された ${ }^{33)}$. IL-12 は p35 と p40のへテロ ダイマーよりなり ABT-874/J695 は p40 に対する 抗体である.79名のクローン病患者を対象にプラ セボとの二重盲検試験が行われ， $3 \mathrm{mg} / \mathrm{kg} /$ 週の 7 週連続投与において有意差をもって有効性が示され た.しかし，その後の基礎研究から各炎症性疾患に おいて IL-23 および Th-17 免疫応答の関与が議論 されるようになり炎症性腸疾患, 特にクローン病に おいても注目されるようになった。 IL-23 は p40 と p19のヘテロダイマーからなり，p40 という IL-12 と共通のサブユニットを有する.したがって ABT874/J695 が IL-12 あるいは IL-23 のいずれか，も しくは両者を抑制しているのかが明らかではない. また各炎症性疾患に打ける IL-12 と IL-23 の関与 についても相乗作用を持つのか，あるいは拮抗する のかについて意見がまとまっていない，また多くの 研究はマウスを用いられているがヒトにおける IL23 の働きがマウスと異なる可能性も指摘されてお りさらなる大規模試験においてこの抗体がクローン 病に有効なのか，そのメカニズムは何かが明らかに なることが期待される。

\section{3. 抗 IFN $-\gamma$ 抗体（Fontlizumab 商品名： HuZAF)}

これまでの基礎的研究からクローン病の腸管局所 での免疫応答は Th-1 型ヘシフトしていることが明 らかとなっている. Th-1 型免疫応答の中心となる サイトカイン, IFN- $\gamma$ が病態の中心的役割を担っ ていると考えられてきたことから ${ }^{34,35)}$, IFN- $\gamma$ を標 的とした治療が試みられている. Fontolizumabは ヒト化された抗 IFN- $\gamma$ 抗体で, 中等症から重症 (Crohn's disease activity index ; CDAI $=250-450$ ) のクローン病患者 133 名を対象にプラセボ群，実薬 $4 \mathrm{mg} / \mathrm{kg}$ 群, $10 \mathrm{mg} / \mathrm{kg}$ 群の 3 群比較試験が行われ た. 42 名は単回投与，91 名には第 0 日と第 28 日の 2 回投与が行われた。単回投与における第 28 日時 点での有効率にプラセボ群と実薬群で差は認められ なかったが，2 回投与群において第 56 日時点での 有効率はプラセボ群 $32 \%$ に対し $4 \mathrm{mg} / \mathrm{kg}$ 群， $10 \mathrm{mg}$
$/ \mathrm{kg}$ 群でそれぞれ 69\%,67\%であった ${ }^{36)}$. 安全性と 忍容性についても 45 名の CDAI = 250-450のク ローン病患者において検討が行われ報告された。こ の中で Fontolizumab 自体への抗体産生は 1 例で確 認されたのみであった

\section{4. ヒト化抗 $\alpha 4$ インテグリン抗体}

\section{(Natalizumab 商品名：TYSABRI）}

脳をはじめとするさまざまな臓器はVCAM-1を 発現しており接着分子 $\alpha 4 \beta 1$ インテグリンを発現す るリンパ球のホーミングに関与する. 一方, 腸管へ ホーミングするリンパ球は接着分子として $\alpha 4 \beta 7$ を 発現しており，そのリガンドは血管内皮細胞に発現 する MAdCAM-1 である. Natalizumab は $\alpha 4$ イン テグリンに対するヒト化 IgG4 抗体で 2004 年に米 国で多発性硬化症の治療薬として承認された。 それ に引き続きクローン病に対する臨床治験が行われて いたが38), 途中 JCウィルス再活性化による脱髄性 疾患である進行性多病巣性白質脳症（progressive multifocal leukoencephalopathy ; PML ) で死亡例 が報告され治験が中断された ${ }^{39)}$. その後, 医療従事 者への教育プログラムや使用患者のモニタリングの 徹底化が行われ 2008 年 6 月, 米国食品衛生局は治 療抵抗性の中等度ないし重症のクローン病患者に対 して Natalizumabを承認した。クローン病に対す る Natalizumab の大規模臨床試験は ENACT-1 (Efficacy of Natalizumab as Active Crohn's Therapy) ${ }^{38)}$, ENACT-2 (Evaluation of Natalizumab as Continuous Therapy) ${ }^{40)}$, ENCORE (Efficacy of Natalizumab in Crohn's disease Response and Remission) ${ }^{41)}$ がある. ENACT-1 試験では 905 例の 中等症から重症のクローン病患者に対して Natalizumab $300 \mathrm{mg}$ もしはプラセボが第 $0,4,8$ 週に投与された。第 10 週での評価では有効率も緩 解率も二群間で差を認めなかった。しかし，CRP 陽性の患者に限定したサブ解析では有効率, 緩解率 ともに有意差が得られた。 ENACT-2 試験では ENACT-1 試験で Natalizumab が有効であった 339 例の患者に対して $300 \mathrm{mg}$ の実薬もしくはプラセボ が 4 週ごと第 56 週まで投与された. この試験で第 36 週での有効性維持率と緩解率に有意差が認めら れた. ENCORE 試験は CRP 陽性の中等症から重 症のクローン病患者 509 例に限定してプラセボとの 比較試験が行われ第 8 週 12 週までの有効性維持 率と緩解率に有意差が認められた。 また，第 4,8 , 
12 週時点での有効率, 緩解率はともに実薬群が上 回っていた.

\section{5. ヒト化抗 $\alpha 4 \beta 7$ インテグリン抗体（MLN02）}

先に述べたように $\alpha 4$ インテグリンはさまざまな 蔵器へホーミングするリンパ球に共通のインテグリ ンである.より腸管特異的にリンパ球のリクルート を阻害するために $\alpha 4 \beta 7$ 特異的なと卜化抗 $\alpha 4 \beta 7$ イ ンテグリン抗体（MLN02）が開発され, 活動性潰 瘍性大腸炎に対する臨床試験が行われた 42 .

\section{6. $\mathrm{AJM}-300$}

我が国で開発された $\alpha 4$ インテグリンを阻害する 低分子化合物である。すでにクローン病に対する第 2 相臨床試験が終了している。この試験では Crohn Disease Activity Index (CDAI) $>150$ の活動性ク ローン病を対象にプラセボ, $40 \mathrm{mg}, 120 \mathrm{mg}, 240$ $\mathrm{mg}$ 投与群の 4 群比較で行われた. 特に CDAI $\geq$ 200 の患者群の部分解析において $240 \mathrm{mg}$ 投与群で 臨床的有効性，CRP の低下などが証明された。こ れを受けて, 用量を変更し（プラセボ， $240 \mathrm{mg}$, $480 \mathrm{mg}$ 投与群の 3 群)，CDAI > 220 の活動性ク ローン病を対象とした緩解導入療法の第 2,3 相臨 床試験が実施される予定である．Natalizumabなど の抗体製剤と異なり経口投与による分子標的薬であ ること, 半減期が短く副作用にも対応しやすいこと などから期待されている.

\section{X.おわりに}

炎症性腸疾患の病態については遺伝子分子生物 学, 免疫学の進歩による解明が進み, 機能分子の同 定とそれを標的とする治療法の開発が進んでおり， その最たる成功例が抗 TNF $\alpha$ 抗体である Infliximab である、すでに Infliximab はステロイド抵抗性や瘻 孔合併クローン病患者に扔いて劇的な効果を示して 抢り患者の QOL の向上に大きく寄与している.し かし, クローン病全体では Infliximab による緩解導 入率は約 40\%程度であり，また継続投与に伴う治 療効果の減弱なぞ解決されるべき問題は多い。いっ ぽう Top-down therapy の考え方はこれまで成し得 なかったクローン病の自然史の改善，すなわち “care”から“cure”を目指した治療への可能性を 秘めている.今後は安全性や医療コスト，その導入 基準や時期などが検討されるべき課題であろう。ま た潰瘍性大腸炎への Infliximab の臨床応用も期待さ
れている．特に維持投与により再然を抑えることが できればシクロスポリンなどの強力な急性期治療を もってしてもこれまで解決されなかった緩解維持と いう点からも極めて有望である.さらに TNF 阻害 剤に引き続いて多くの生物製剤が開発され臨床応用 されようとしている．生物製剤の開発により炎症性 腸疾患の治療体系は今後大きく改変されていくこと は疑う余地が無い.いっぽうで決して濫用すること なく科学的根拠に基づいた適正使用や適応症例の確 立が我々に課せられた使命であろう。

\section{文献}

1) Maini RN, Brennan FM, Williams $R$, Chu $C Q$, Cope AP, Gibbons D, Elliott M, Feldmann M. : TNF-alpha in rheumatoid arthritis and prospects of anti-TNF therapy. Clin Exp Rheumatol 11 (Suppl 8) : S173-175, 1993.

2) van Dullemen HM, van Deventer SJ, Hommes DW, Bijl HA, Jansen J, Tytgat GN, Woody J. : Treatment of Crohn's disease with anti-tumor necrosis factor chimeric monoclonal antibody (cA2). Gastroenterology 109 : 129-135, 1995.

3) Targan SR, Hanauer SB, van Deventer SJ, Mayer L, Present DH, Braakman T, DeWoody KL, Schaible TF, Rutgeerts PJ. : A short-term study of chimeric monoclonal antibody cA2 to tumor necrosis factor alpha for Crohn's disease. Crohn's Disease cA2 Study Group. $N$ Engl J Med 337 : 1029-1035, 1997.

4) D'Haens G, Van Deventer S, Van Hogezand R, Chalmers D, Kothe C, Baert F, Braakman T, Schaible T, Geboes K, Rutgeerts P. : Endoscopic and histological healing with infliximab antitumor necrosis factor antibodies in Crohn's disease : A European multicenter trial. Gastroenterology 116 : 1029-1034, 1999.

5) Present $D H$, Rutgeerts $P$, Targan $S$, Hanauer SB, Mayer L, van Hogezand RA, Podolsky DK, Sands BE, Braakman T, DeWoody KL, Schaible TF, van Deventer SJ. : Infliximab for the treatment of fistulas in patients with Crohn's disease. $N$ Engl J Med 340 : 13981405, 1999.

6) Rutgeerts P, D'Haens G, Targan S, Vasiliauskas E, Hanauer SB, Present DH, Mayer L, Van Hogezand RA, Braakman T, DeWoody KL, Schaible TF, Van Deventer SJ. : Efficacy and safety of retreatment with anti-tumor necrosis factor antibody (infliximab) to maintain remis- 
sion in Crohn's disease. Gastroenterology 117 : 761-769, 1999.

7) Hanauer SB, Feagan BG, Lichtenstein GR, Mayer LF, Schreiber S, Colombel JF, Rachmilewitz D, Wolf DC, Olson A, Bao W, Rutgeerts P.: Maintenance infliximab for Crohn's disease : the ACCENT I randomised trial. Lancet 359 : 1541-1549, 2002.

8) Sands BE, Blank MA, Patel K, van Deventer SJ. : Long-term treatment of rectovaginal fistulas in Crohn's disease : response to infliximab in the ACCENT II Study. Clin Gastroenterol Hepatol 2 : 912-920, 2004.

9) Rutgeerts P, Feagan BG, Lichtenstein GR, Mayer LF, Schreiber S, Colombel JF, Rachmilewitz D, Wolf DC, Olson A, Bao W, Hanauer SB. : Comparison of scheduled and episodic treatment strategies of infliximab in Crohn's disease. Gastroenterology 126 : 402413, 2004.

10) van Deventer SJ. : Transmembrane TNF-alpha, induction of apoptosis, and the efficacy of TNF-targeting therapies in Crohn's disease. Gastroenterology 121 : 1242-1246, 2001.

11) Lugering A, Schmidt M, Lugering N, Pauels HG, Domschke W, Kucharzik T. : Infliximab induces apoptosis in monocytes from patients with chronic active Crohn's disease by using a caspase-dependent pathway. Gastroenterology 121 : 1145-1157, 2001.

12) Garrett WS, Lord GM, Punit $S$, Lugo-Villarino G, Mazmanian SK, Ito S, Glickman JN, Glimcher LH. : Communicable ulcerative colitis induced by $\mathrm{T}$-bet deficiency in the innate immune system. Cell 131 : 33-45, 2007.

13) Nenci A, Becker C, Wullaert A, Gareus R, van Loo G, Danese S, Huth M, Nikolaev A, Neufert C, Madison B, Gumucio D, Neurath MF, Pasparakis M. : Epithelial NEMO links innate immunity to chronic intestinal inflammation. Nature 446 : 557-561, 2007.

14) Zaph C, Troy AE, Taylor BC, Berman-Booty LD, Guild KJ, Du Y, Yost EA, Gruber AD, May MJ, Greten FR, Eckmann L, Karin M, Artis D. : Epithelial-cell-intrinsic IKK-beta expression regulates intestinal immune homeostasis. Nature 446 : 552-556, 2007.

15) Zeissig S, Bojarski C, Buergel N, Mankertz J, Zeitz M, Fromm M, Schulzke JD. : Downregulation of epithelial apoptosis and barrier repair in active Crohn's disease by tumour necrosis factor alpha antibody treatment. Gut $\mathbf{5 3}$ : 12951302, 2004.

16) Youdim A, Vasiliauskas EA, Targan SR, Papadakis KA, Ippoliti A, Dubinsky MC, Lechago J, Paavola J, Loane J, Lee SK, Gaiennie J, Smith K, Do J, Abreu MT. : A pilot study of adalimumab in infliximab-allergic patients. Inflamm Bowel Dis 10 : 333-338, 2004.

17) Hanauer SB, Sandborn WJ, Rutgeerts $P$, Fedorak RN, Lukas M, MacIntosh D, Panaccione R, Wolf D, Pollack P.: Human antitumor necrosis factor monoclonal antibody (adalimumab) in Crohn's disease : the CLASSIC-I trial. Gastroenterology $130: 323-333$, 2006.

18) Colombel JF, Sandborn WJ, Rutgeerts P, Enns R, Hanauer SB, Panaccione R, Schreiber S, Byczkowski D, Li J, Kent JD, Pollack PF.: Adalimumab for maintenance of clinical response and remission in patients with Crohn's disease : the CHARM trial. Gastroenterology 132 : 52-65, 2007.

19) Sandborn WJ, Rutgeerts $P$, Enns R, Hanauer SB, Colombel JF, Panaccione R, D'Haens G, Li J, Rosenfeld MR, Kent JD, Pollack PF.: Adalimumab induction therapy for Crohn disease previously treated with infliximab : a randomized trial. Ann Intern Med 146 : 829-838, 2007.

20) Schreiber S, Rutgeerts P, Fedorak RN, KhaliqKareemi M, Kamm MA, Boivin M, Bernstein $\mathrm{CN}$, Staun M, Thomsen OO, Innes A. : A randomized, placebo-controlled trial of certolizumab pegol (CDP870) for treatment of Crohn's disease. Gastroenterology 129: 807818, 2005.

21) Sandborn WJ, Feagan BG, Stoinov S, Honiball PJ, Rutgeerts P, Mason D, Bloomfield R, Schreiber S. : Certolizumab pegol for the treatment of Crohn's disease. $N$ Engl J Med 357 : 228-238, 2007.

22) Schreiber S, Khaliq-Kareemi M, Lawrance IC, Thomsen OO, Hanauer SB, McColm J, Bloomfield R, Sandborn WJ. : Maintenance therapy with certolizumab pegol for Crohn's disease. $N$ Engl J Med 357 : 239-250, 2007.

23) Sandborn WJ, Hanauer SB, Katz S, Safdi M, Wolf DG, Baerg RD, Tremaine WJ, Johnson T, Diehl NN, Zinsmeister AR. : Etanercept for active Crohn's disease : a randomized, doubleblind, placebo-controlled trial. Gastroenterolo- 
gy 121 : 1088-1094, 2001.

24) Marzo-Ortega $\mathrm{H}, \mathrm{McG}$ conagle $\mathrm{D}$, O'Connor $\mathrm{P}$, Emery P. : Efficacy of etanercept for treatment of Crohn's related spondyloarthritis but not colitis. Ann Rheum Dis 62 : 74-76, 2003.

25) Baert F, Noman M, Vermeire S, Van Assche G, G DH, Carbonez A, Rutgeerts P. : Influence of immunogenicity on the long-term efficacy of infliximab in Crohn's disease. $N \mathrm{Engl} \mathrm{J} \mathrm{Med}$ $348: 601-608,2003$.

26) Hanauer SB. : Top-down versus step-up approaches to chronic inflammatory bowel disease : presumed innocent or presumed guilty. Nat Clin Pract Gastroenterol Hepatol 2 : 493, 2005.

27) Goekoop-Ruiterman YP, de Vries-Bouwstra JK, Allaart CF, van Zeben D, Kerstens PJ, Hazes JM, Zwinderman AH, Ronday HK, Han KH, Westedt ML, Gerards AH, van Groenendael JH, Lems WF, van Krugten MV, Breedveld FC, Dijkmans BA. : Clinical and radiographic outcomes of four different treatment strategies in patients with early rheumatoid arthritis (the BeSt study) : a randomized, controlled trial. Arthritis Rheum 52:3381-3390, 2005.

28) D’Haens G, Baert F, van Assche G, Caenepeel $\mathrm{P}$, Vergauwe P, Tuynman H, De Vos M, van Deventer S, Stitt L, Donner A, Vermeire S, Van de Mierop FJ, Coche JC, van der Woude J, Ochsenkuhn $\mathrm{T}$, van Bodegraven AA, Van Hootegem PP, Lambrecht GL, Mana F, Rutgeerts P, Feagan BG, Hommes D. : Early combined immunosuppression or conventional management in patients with newly diagnosed Crohn's disease: an open randomised trial. Lancet 371 : 660-667, 2008.

29) Hyams J, Crandall W, Kugathasan S, Griffiths A, Olson A, Johanns J, Liu G, Travers S, Heuschkel R, Markowitz J, Cohen S, Winter H, Veereman-Wauters G, Ferry G, Baldassano R. : Induction and maintenance infliximab therapy for the treatment of moderate-to-severe Crohn's disease in children. Gastroenterology 132 : 863-873, 2007.

30) Jarnerot G, Hertervig E, Friis-Liby I, Blomquist L, Karlen P, Granno C, Vilien M, Strom M, Danielsson A, Verbaan H, Hellstrom PM, Magnuson A, Curman B. : Infliximab as rescue therapy in severe to moderately severe ulcerative colitis : a randomized, placebo-controlled study. Gastroenterology 128 : 1805-1811, 2005.

31) Rutgeerts P, Sandborn WJ, Feagan BG, Reinisch W, Olson A, Johanns J, Travers S, Rachmilewitz D, Hanauer SB, Lichtenstein GR, de Villiers WJ, Present D, Sands BE, Colombel JF. : Infliximab for induction and maintenance therapy for ulcerative colitis. $N$ Engl $\mathrm{J} \mathrm{Med}$ 353 : 2462-2476, 2005.

32) Ito H, Takazoe M, Fukuda Y, Hibi T, Kusugami K, Andoh A, Matsumoto T, Yamamura $\mathrm{T}$, Azuma J, Nishimoto N, Yoshizaki K, Shimoyama T, Kishimoto T.: A pilot randomized trial of a human anti-interleukin-6 receptor monoclonal antibody in active Crohn's disease. Gastroenterology 126 : 989-996, 2004.

33) Mannon PJ, Fuss IJ, Mayer L, Elson CO, Sandborn WJ, Present D, Dolin B, Goodman N, Groden C, Hornung RL, Quezado M, Yang Z, Neurath MF, Salfeld J, Veldman GM, Schwertschlag U, Strober W. : Anti-interleukin-12 antibody for active Crohn's disease. $N$ Engl J Med 351 : 2069-2079, 2004.

34) Matsuoka $K$, Inoue $N$, Sato $T$, Okamoto $S$, Hisamatsu T, Kishi Y, Sakuraba A, Hitotsumatsu O, Ogata H, Koganei K, Fukushima T, Kanai T, Watanabe M, Ishii H, Hibi T. : T-bet upregulation and subsequent interleukin 12 stimulation are essential for induction of Th1 mediated immunopathology in Crohn's disease. Gut 53 : 1303-1308, 2004.

35) Kamada N, Hisamatsu $T$, Okamoto $S$, Chinen H, Kobayashi T, Sato T, Sakuraba A, Kitazume MT, Sugita A, Koganei K, Akagawa KS, Hibi T. : Unique CD14 intestinal macrophages contribute to the pathogenesis of Crohn disease via IL-23/IFN-gamma axis. J Clin Invest 118 : 2269-2280, 2008.

36) Hommes DW, Mikhajlova TL, Stoinov S, Stimac D, Vucelic B, Lonovics J, Zakuciova M, D’Haens G, Van Assche G, Ba S, Lee S, Pearce T. : Fontolizumab, a humanised anti-interferon gamma antibody, demonstrates safety and clinical activity in patients with moderate to severe Crohn's disease. Gut 55 : 1131-1137, 2006.

37) Reinisch W, Hommes DW, Van Assche G, Colombel JF, Gendre JP, Oldenburg B, Teml A, Geboes K, Ding H, Zhang L, Tang $M$, Cheng M, van Deventer SJ, Rutgeerts P, Pearce T. : A dose escalating, placebo controlled, double blind, single dose and multidose, safety and tolerability study of fontolizumab, a humanised 
anti-interferon gamma antibody, in patients with moderate to severe Crohn's disease. Gut 55 : 1138-1144, 2006.

38) Sandborn WJ, Colombel JF, Enns R, Feagan BG, Hanauer SB, Lawrance IC, Panaccione R, Sanders M, Schreiber S, Targan S, van Deventer S, Goldblum R, Despain D, Hogge GS, Rutgeerts P.: Natalizumab induction and maintenance therapy for Crohn's disease. $N$ Engl $J$ Med 353 : 1912-1925, 2005.

39) Van Assche G, Van Ranst M, Sciot R, Dubois B, Vermeire S, Noman M, Verbeeck J, Geboes K, Robberecht W, Rutgeerts P. : Progressive multifocal leukoencephalopathy after natalizumab therapy for Crohn's disease. $N$ Engl $J$ Med 353 : 362-368, 2005.
40) Feagan BG, Sandborn WJ, Hass S, Niecko T, White J. : Health-related quality of life during natalizumab maintenance therapy for Crohn's disease. Am J Gastroenterol 102 : 2737-2746, 2007.

41) Targan SR, Feagan BG, Fedorak RN, Lashner BA, Panaccione R, Present DH, Spehlmann ME, Rutgeerts PJ, Tulassay Z, Volfova M, Wolf DC, Hernandez C, Bornstein J, Sandborn WJ. : Natalizumab for the treatment of active Crohn's disease : results of the ENCORE Trial. Gastroenterology 132 : 1672-1683, 2007.

42) D'Haens G, Daperno M. : Advances in biologic therapy for ulcerative colitis and Crohn's disease. Curr Gastroenterol Rep 8 : 506-512, 2006. 